\author{
Кололійчук К. М., \\ випускниия магістратури фбілологічного фбакультету \\ Одеського національного університету ілені I. I. Мечникова, \\ вчитель російської мови та літератури \\ ТОВ «Одеський приватний навчально-виховний колплекс \\ "Загальноосвітня школа-ліцей «Просвіта»
}

\title{
СЕМАНТИКО-СТИЛІСТИЧНІ ОСОБЛИВОСТІ ВИГУКІВ В УКРАЇНСЬКОМУ ФОЛЬКЛОРІ
}

\begin{abstract}
Анотація. У статті досліджено семантику вигуків як емотивних назв на матеріалі українських народних пісень та дум. Вигуки як емоційно забарвлена лексика не просто можуть передавати емоції, а й можуть вимагати від реципієнта певних дій або вчинків, маючи ключову роль у формуванні лексико-семантичного і мовного рівня поетичних текстів. Дослідження відображає один з аспектів аналізу вигуків і в морфологічному плані, а саме 3 боку їхньӧ структури та семантики. У вигуках поєднується стабільність (незмінність) форми, рухливість семантики, певна автономність і велика залежність від контексту, ситуації мовлення, паралінгвістичних засобів. Також подаються відомості про вираження вигуками в тексті насамперед емоційно-чуттєвого, психічного стана мовця, його реакції на зовнішні та внутрішні подразники. На основі проведеного аналізу виявилось, що вигуки не називають почуттів, експресивних оцінок, вольових спонукань, а безпосередньо виражають їх. Можна вважати, що такі лексеми $\epsilon$ не просто звуками, а осмисленими елементами мови, що зумовлює їхню однозначність, яку в живому спілкуванні зрозуміло із комунікативної ситуації, а в текстах - із контексту. У художніх творах, у фольклорі семантика вигуків передається також через опис супроводжувальних жестів, міміки, іноді - через інтонацію. Особливо детально аналізується семантичне призначення емотивної лексики, яке полягає не тільки в номінації денотата, а й у вираженні емоційного ставлення мовця до нього, до предмета мовлення чи до ситуації спілкування. Саме це відрізняє емотивну лексику від номінативної, призначенням якої $є$ найменування предметів. Описується вираження емоцій як основна функція вигуків. Їх роллю в побудові мовлення $\epsilon$ введення мовної реакції партнера або відкриття висловлювання мовця. Тому вигуки можна назвати розмовними словами, які виражають позиції та реакції співрозмовника. У зв'язку з тим, що семантичне значення вигуків дуже розпливчасте і його можна позначити узагальнено як вираження емоцій, лінгвісти намагаються дати свої семантичні класифікації, конкретизуючи семантичне значення на різних підставах.
\end{abstract}

Ключові слова: емотиви, емоція, вигуки, семантика, народна творчість, контекст, інтерпретація.

Постановка проблеми. У літературі велике питання викликає класифікація вигуків як специфічних мовних знаків, їхня складна природа породжує різні класифікації. Насамперед семантика вигуків полягає в домінантній ролі контексту та інтонації, в реченні вигуки виконують комунікативну й емотивну функції, що свідчить про їх важливу роль у мовленнєвому акті $[9$, с. 30]. Вважається, що вигуки взагалі не мають предметно-логічного значення: не означають поняття, але виражають емоції.

Аналіз останніх досліджень і публлікацій. Вигуки завжди привертали увагу лінгвістів багатьох країн світу. Питання вигуків, принципи їх класифікації досліджували О.О. Потебня, О.О. Шахматов, В.В. Виноградов, Л.В. Щерба, А. Вежбицька (на матеріалі російської мови); І.Р. Вихованець, Л.І. Мацько (на матеріалі української мови); Є.Є. Корді, Ж. Вандрієс (на матеріалі французької мови), Ч. Фріз, С. Грінбаум, О. Єсперсен (на матеріалі англійської мови); Г. Вайнріх, І. Ербен, А.Т. Кривоносов, В.Д. Девкін та І. Буша (на матеріалі німецької мови) та багато інших дослідників [9, с. 31].

Актуальність наукової статті полягає в тому, що вона повністю показує структуру та семантику вигуків, оскільки вони є рідкісним явищем і в семантичному, і в морфологічному плані.

Мета статті - здійснити семантико-стилістичний аналіз вигуків, які являються одиницями українського фольклору. Для реалізації цієї мети передусім постають такі завдання: 1) проаналізувати емоційну лексику вигуків; 2) схарактеризувати семантичні особливості вигуків як мовних одиниць.

Виклад основного матеріалу. Вивчення емоцій та їх роль у житті людини завжди цікавило вчених, дослідників, які працюють у галузі цілого ряду наук, таких як філософія, фізіологія, психологія, лінгвістика тощо. Такий підхід не є випадковим, оскільки проблеми емоцій у житті людини є багатогранними. Емоції є невід'ємною складовою частиною психології людини, вони виявляються певною мірою в усіх сферах ії діяльності, в усіх сферах іiі духовного життя, зокрема у сфері спілкування вербального та невербального.

Вивченням емоцій у різні часи займались такі науковці, як Ч. Дарвін, С. Рубінштейн, Г. Костюк, А. Петровський, У. Джеймс, К. Ленге, 3. Фройд, П. Анохін, П. Симонов, Б. Базима та інші. У контексті сучасної антропологічної лінгвістичної парадигми виникає необхідність дослідження сфери емоцій. Проблемою вираження емотивності в тексті займалися такі вчені, як О.Є. Філімонова, І.М. Джобава, Є.В. Вакуленко, Т.В. Горшкова, П.С. Волкова, Л.А. Калімуліна тощо. Варто зазначити, що незважаючи на те, що емоції були об'єктом дослідження в лінгвістиці (А. Вежбицька, В.Г. Гак, Дж. Лакофф, Н.А. Красавський, В.В. Леонтьєв, В.І. Шаховський та інші), все ще залишається нерозв'язаною низка проблем.

На відміну від французьких лінгвістів, які дотримувалися думки, що лише деякі слова мають емоційний компонент, а більшість словникового запасу мови має нейтральне забарв- 
лення, вітчизняні психолінгвісти (зокрема, В.І. Шаховський) вважають такий поділ неправильним і переконані, що кожне слово може мати емоційний заряд [11, с. 81].

Семантичне призначення емотивної лексики полягає не тільки в номінації денотата, а й у вираженні емоційного ставлення мовця до нього, до предмета мовлення чи до ситуації спілкування. Саме це відрізняє емотивну лексику від номінативної, призначенням якої є найменування предметів і т. д. Лексика називання та опису емоцій є за своєю семантикою нейтральною. Лексичний фонд власне емотивних засобів мови формують емотиви - спеціальні лексичні одиниці, що виражають емоції. У своїй семантичній структурі вони обов'язково містять емоційний компонент.

До емоційних відносять слова, що називають психічні, внутрішні стани, характер, переживання (радість, любов, щастя, сум, нудьга тощо); будь-яке поняття 3 одним компонентом або позитивним, або негативним. Також до емоційних належать слова з оцінними значеннями, що виявляються в певних характеристичних ознаках, наприклад: характеристика людей (красень, лебідонька); характеристика навколишнього світу, будівель (хороми); емоційна кваліфікація дій людини, процесу говоріння (базікати). Варто виокремлювати також емоційні слова і словосполучення: слова, що містять у своєму лексичному значенні емоційне забарвлення - позитивне чи негативне (милий, ласкавий); слова, в лексичному значенні яких емоційність привноситься афіксами (земелька, чорнявенький). Основною умовою для відокремлення емоційних слів і словосполучень також уважаємо здатність самого слова виражати почуття, емоції; необхідність відповідного контексту, що надає слову відповідного емоційного звучання. До емоційних слів належать слова, які виконують специфічно-стилістичні функції і виступають у ролі образних символів. Основним смисловим навантаженням емоційної лексики в українській мові виступає вираження почуттів і настроїв людини.

Серед лексики, що виражає емоції, особливе місце займають вигуки. У лінгвістичній науці вивченню вигуків присвячені праці В. Виноградова, І. Міщанінова, О. Потебні, О. Шахматова, Е. Гоффмана, Дж. Ліча. Деякі лінгвісти (Р.А. Бурдакова, Є.Є. Корді, А.А. Реформатський, Г.М. Кузенко) вважають, що вигуки взагалі не мають предметно-логічного значення: не означають поняття, але виражають емоції. Наприклад: «Тату!», «Чортів день!», «Замовкни!», «Вгору!», «О ні!» та ін. У реченні вигуки виконують комунікативну й емотивну функції, що свідчить про їх важливу роль у мовленнєвому акті.

Особливим полотном для використання емотивів є народна творчість. Народно-пісенна мова надзвичайно багата лексикою, яка передає емоційний стан чи дає емоційну оцінку людям, подіям тощо. Емоції в народних думах та історичних піснях можуть бути виражені різними засобами, зокрема й вигуками. Вигуки не називають почуттів, експресивних оцінок, вольових спонукань, а безпосередньо виражають їх. Можна вважати, що такі лексеми $€$ не просто звуками, а осмисленими елементами мови, що зумовлює їхню однозначність, яку в живому спілкуванні зрозуміло із комунікативної ситуації, а в текстах - із контексту. У художніх творах, у фольклорі семантика вигуків передається також через опис супроводжувальних жестів, міміки, іноді - через інтонацію.

Поза контекстом більшість вигуків має широкий спектр емоційного забарвлення: від вираження негативних емоцій до позитивних, тому, як зазначає Т.А. Оришечко, «інтерпретація широкого значення можлива лише в найзагальніших формах і ніколи не може бути рівною та однаковою визначенню його конкретизованого варіанту в кожному окремо взятому випадку функціонування даного слова» [7, с. 332].

Наприклад, вигук ox може вживатися для вираження фізичного болю, страждання, переляку, відчуття полегшення, для висловлення застереження, попередження про що-небудь небажане, неприємне, для вираження почуття жалю, досади, невдоволення, докору, захоплення, подиву, для вирізнення, підсилення якого-небудь слова, вислову [2, с. 34]. Разом із тим існують вигуки, емоційне поле яких значно вужче, наприклад mbxy, який виражає здивування, невдоволення, досаду [2, с. 34].

Найчастотнішими в дослідженому матеріалі [9, с. 145] $€$ вигуки ой і ox.

Вигук ой передає такі емоції:

1) захоплення (ой, на горі да женці жнуть; ой, послав Бог Хмельницького; ой, які пішли козаченьки в битву; ой, як поӥхав наш пан Лебеденко; ой, був на Січі старий козак Сава; ой, червонії квітки; ой, тепер ми господарі);

2) зацікавленість (ой, щз то за крячок);

3) розчарування (ой, вийду я на могилу; ой, все лужком та все бережком; ой, нікому так не горе; ой, наварили ляхи пива);

4) ненависть (ой, Петлюро, вражсий сину!);

5) прохання (ой, Богдане, батьку Хмелю; ой, ти, Морозенку);

6) співчуття та співпереживання (ой, Богдане-Богданочку!; ой, попід гай зелененький везли Довбуша);

7) надії (ой, галочки-сизоперочки; ой, пише-пише сотник Поволоиький; ой, же хлопиі не співали; ой, летіла зозулечка понад гори й села; ой, посіяла я хліб; ой, браття, браття, будуймо; ой, то в полі не вітри);

8) зневіри (ой, судома, пане-брате, судома, судома; ой, закурила, затопила сирими дровами; ой, тяжко козакові в неволі сидіти; ой, високо соние сходить, а низько заходить; ой, горе нам молодим; ой, Канадо-Канадочко, Канадо-небого);

9) переляк, тривога (та ой, та як крикнув же козак Сірко; ой, зачула ж моя доля; ой, чи воля чи неволя; ой, заграло Чорне море; ой, котився вітер яром; ой, чого ж ти земле, молодіти стала).

Вигук $о x$ фіксуємо для передачі таких емоцій:

1) захоплення (ох, як пішов же наш пан!);

2) розчарування (ох, ти ж, сину, нетямущий);

3) співчуття (ох, тяжко козакові в неволі сидіти).

Рідше зустрічаємо вигук гей, який передає такий спектр емоцій:

1) заклик, підняття бойового духу (гей, ви, хлопиі-партизани; гей, несись наш спів над морем);

2) розрада, підтримка (гей, хто, хто горя не знає; гей, ще соние не зійшло);

3) розчарування (гей, да журба мене скрутила; гей, на біду, на горе);

4) радість (гей, заспівало все в Kарпатах).

У текстах народних пісень побутують вигуки долой (долой панів, долой царя), ну-бо (ну-бо, хлопиі, повстаньмо), які передають емоцію гніву. Це можна пояснити історичними причинами, а саме знущанням панів та царів над простим людом, які намагалися хоча б у піснях побороти їхні утиски й підняти власний волелюбний дух. 
Фіксуємо також вигуки-повтори, типу гай-гай (А стара Мавра! Гай, гай, хто так уміє сторожити над дівчиною, як сама вона!).

Вигук гай, гай вжито, за контекстом, для вираження смутку, розчарування. Ключем для визначення характеру емоційного насичення на лексичному рівні $€$ підрядне речення «хто так уміс сторожити над дівчиною», яке раціоналізує емоції вигуку та подальші події за текстом «не зберегла дівчину стара Мавра»; на пунктуаційному рівні вигуки виділено комами.

Висновки. Більшість учених структурно поділяє вигуки на первинні та вторинні. Первинні вигуки за своєю структурою однослівні, а вторинні вигуки можуть складатися: а) 3 одного слова; б) з декількох слів; в) із цілих речень. Семантичне значення більшості вигуків не зосереджено в даній одиниці як мовному знакові, а випливає з контексту, ситуації мовлення, наповнюється і увиразнюється паралінгвістичними засобами. Варто відзначити, що вигуки як емоційно забарвлена лексика не просто можуть передавати емоції, побажання, а й можуть вимагати від реципієнта певних дій або вчинків. У народних піснях найповніше реалізується притаманна нашому етносу семантика лексичних об'єднань, зокрема досліджувана нами емоційна лексика.

Перспективи подальшого дослідження полягають в аналізі морфосинтаксичних особливостей вигуків. Виникає потреба у створенні гнучкої та логічної класифікації, що охоплює основні великі групи, які відрізнятимуться одна від одної суттєвими ознаками.

\section{Jimepamypa:}

1. Бондалетов В.Д. Русская ономастика : монография. Москва : Просвещение, 1983. 224 с.

2. Великий тлумачний словник української мови (з дод. і допов.) / уклад. і голов. ред. В.Т. Бусел. Київ ; Ірпінь : ВТФ «Перун», 2005. $1728 \mathrm{c}$.

3. Іванова Н.Д. Семантичні особливості лексики на позначення емоцій в українських народних піснях. Наукові праці Чорноморського державного університету імені Петра Могили. Сер. «Філологія. Мовознавство». 2011. Т. 148. Вип. 136. С. 32-35.

4. Карпенко Ю.О. Мова та стиль українського фольклору : зб. наук. праць /за ред. кол. : Ю.О. Карпенко (відп. ред.) та ін. Київ, 1996. $164 \mathrm{c}$.

5. Кузенко Г.М. Емотивність на різних мовних рівнях. Наукові записки. Філологічні науки. Національний університет «Києво-Могилянська академія». Київ : Видавничий дім «КМ Академія», 2000. Т. 18. С. 76-82.

6. Кузенко Г.М. Мовні засоби вираження емотивності. Наукові записки НаУКМА. 2000. Т. 18: Філологічні науки. С. 76-83.

7. Оришечко Т.А. Відтворення вигуків як слів з розмитою семантикою у художньому перекладі. Актуальні проблеми слов'янської філології. Серія «Лінгвістика і літературознавство» : Міжвуз. 3б. наук. ст. 2010. Вип. ХХІІІ. Ч. 3. С. 331-339.

8. Селігей П.О. Як українціговорять про свої думки та емоції. Українська мова та література. 2005. С. 7-10.
9. Пилипко О.І. Структурно-семантичні особливості вигуків у сучасній німецькій мові. Науковий вісник Східноєвропейського національного університету ім. Лесі Українки. Серія «Граматична семантика» : Міжвуж. зб. наук. ст. 2013. С. 29-33.

10. Українські народні думи та історичні пісні : Збірник. Київ, $1955.670 \mathrm{c}$.

11. Чабаненко В.А. Стилістика експресивних засобів виявлення української мови. Запоріжжя : ЗДУ, 2002. 351 с.

12. Шаховский В.И. О лингвистике эмоций. Язык и эмочии. Волгоград : Перемена, 1995. С. 3-15.

\section{Kolomiichuk K. Semantics of exclamations in Ukrainian folklore}

Summary. This article examines the semantics of whigs as emotional names on the material of Ukrainian folk songs and poems. Viguks, as emotionally charged vocabulary, can not only convey emotions, but can also demand certain actions or inactions from the recipient. The key role in the formation of lexical-semantic and linguistic level of poetic texts. The study depicts one of the aspects of the analysis of whispers, namely from the side of their structure and semantics, and from the morphological point of view. Whiggles combine the stability (immutability) of the form, the fluidity of semantics, a certain autonomy and great dependence on the context, the situation of language, paralinguistic devices. The text also provides information about the expression of whigs in the text, in particular about the emotional and sensitive, psychological state of the speaker, his reaction to external and internal subdivisions. On the basis of the carried out analysis, it has appeared, that whigs do not name feelings, expressive estimations, volitional spokes, but indirectly express them. It can be argued that these lexemes are not just sounds, but are meaningful elements of language, which determines their unambiguity, which in a live conversation is understood from the communicative situation, and in texts - from the context. In works of art and folklore the semantics of wiggles is also conveyed through the description of accompanying gestures, mimicry, sometimes - through intonation. The semantic purpose of the emotive vocabulary was analyzed in particular detail, which consists not only in denotation, but also in expressing the emotional attitude of the speaker to him or her, to the subject of the conversation or to the situation of the conversation. This is what distinguishes the emotional vocabulary from the nominative vocabulary, the purpose of which is the naming of objects. It describes the expression of emotions as the main function of the vocabulary. İx role in the production of speech is the introduction of the partner's verbal reaction, or the opening of the verbal expression of the speaker. That is why whispers can be called rozumovymi words, which express the positions and reactions of the spouse. Due to the fact that the semantic meaning of whispers is very disperse and can be categorized generically as expression of emotions, linguists try to give their own semantic classifications, specifying the semantic meaning on various bases.

Key words: emotives, emotion, exclamations, semantics, folk art, context, interpretation. 